\title{
THE DEVASTATING KERALA FLOOD - 2018 AND IT'S IMPACT ON MARKET TREND TOWARDS CONSUMER DURABLES IN KOTTAYAM
}

\section{Dr. JOJOMON N A \& SWAPNA R}

Associate Professor of Commerce, PM Government College, Potta-Chalakudy, Kerala, India

ABSTRACT
The trail of devastation left by the recent floods in Kerala included 12 lakh people rendered homeless and more than 300
dead. According to initial estimates, property worth more than Rs. 20,000 crore has been lost and insurance companies
is told to have have received claims worth Rs.1,000 crore as per the media information on 28/08/18. As for consumer
goods, Kerala is considered a large market both for consumer durables and non-durables alike. Kerala accounts for 10
percent of the total annual sales of the Rs. 30,000 croreconsumer durable and appliance market. Besides, the Rs.3,000
crore Kerala market has been growing at a rate of $12-15$ percent. However, the rains and floods have washed away $40 \%$
of this year's sales, which usually occurs during onam time (this year 25/08/18). Consumer durables in at least 5,00,000
houses would have been damaged due to flood water. "The initial priority on account of flood was to clean the houses
and make it habitable and also to help people to get basic things like power connections and water supply back into
shape. But down the line when things stabilize there will be huge demand to replace at least essential appliances which
cannot be repaired. This demand will go higher than the usual demand for durables" - estimates $S$ Saji Kumar,
President, CIIK erala.
KEYWORDS: Kerala Flood - 2018, Consumer Durables - T.V, Refrigerator and Washing Machine, Market Trend-
Consumer Buying Behaviour, Manufacturer's and Dealer's Services

Received: Nov 08, 2018; Accepted: Nov 28, 2018; Published: Dec 04, 2018; Paper Id.: IJHRMRDEC201824

\section{INTRODUCTION}

According to the recently released National Family Health Survey 2015-16, 30\% of households in Kerala have at least six of the following assets - pucca house, electricity connection, mobile phone or landline, TV, refrigerator, washing machine, air conditioner, PCs and motorised vehicle. The people living in worst flood affected areas may have lost and would be required to replace or repair some of these assets.

This is going to make Kerala a large market for these items. The probability of refrigerators and televisions being replaced is highest. But given the liquidity crunch, vendors of these items may have to come up with attractive packages. So after an initial lull owing to flood, there will be a huge spurt in the demand for theseitems.

The expected huge spurt in demand for consumer durables especially refrigerators, televisions and washing machines which is owned by majority of middle class families in Kerala formed the basis for this particular research work.

\section{OBJECTIVES OF THE STUDY}

- To study the buyer behavior for consumer durables (T.V, Refrigerator and Washing Machine) in the worst 
flood affected areas of Kottayam, Kerala - post flood vis-à-vispre-flood.

- To analyse the kind of service provisions by the various brands of televisions, refrigerators and washing machines to the flood affected victims ofKottayam.

- To analyse the kind of service provisions by the dealers of various brands of televisions, refrigerators and washing machines to the flood affected victims ofKottayam.

\section{RESEARCH METHODOLOGY}

The data required for carrying out this research work was collected from both primary and secondary sources. Method of Data Collection happened to be Sample Survey. A total of 51 sample units were selected from the Universe which constitutes all the occupants in the areas of Kallara, Thazhathangady, Eranjaal, Thiruvanchoor, SH Mount and Sankranthi (some of the worst flood affected areas of Kottyam). A Combination of Stratified Sampling \& Convenience Sampling was used for the purpose of selecting the 51 sample units. Primary data from the 51 respondents for analysing the buyer behaviour were collected using an interview schedule which was send through my students of second BBA class (Mr. Akhil M.K, Mr.Aleph Saji, Ms.AnjaliSabu, Ms. FidhaShareef, Ms. Jisha Annie Thomas and Mr. Suhail N.N). The enumerators also collected the dealer details through a separate interview schedule. Secondary data relating to the service provisions of various brands and dealers of various brands of consumer durables were collected from newspaper advertisements for a period of one and half months starting from August 20 $0^{\text {th }}, 2018$.

The analysis of the collected data was done using Time Series Analysis, Simple Percentage, Ranking \&LikertScale.

\section{DATA ANALYSIS \& FINDINGS}

- On the buyer behaviour for consumer durables (T.V, Refrigerator and Washing Machine) in the worst flood affected areas of Kottayam, Kerala - post flood vis-à-vispre-flood.

- DEMOGRAPHIC PROFILE OF RESPONDENTS IN FLOOD AFFECTED AREAS OF KOTTAYAM.

- Area and Percentage of Respondents Covered - The percentage of respondents covered in each of the six flood affected areas were almost the same except for Kallara (7.84\%) where the respondents were nonresponsive.

- Education Level of Respondents- Majority of the respondents had an education below Higher Secondary $(78.42 \%)$.

- Occupation of Respondents - Majority(35.29\%) of the respondents were self employed say like farming $25.49 \%$ were private firm employees and another $17.64 \%$ belonged to labourcategory.

- Income Level of Respondents - About $45.09 \%$ of the respondents belonged to the lowest annual income category of "below Rs.10,000/- and another $27.44 \%$ were found to have an annual income between 10,000-20000. That means the chances of repurchase of consumer durables lost in flood was verylow 


\section{PRE AND POST CONSUMER DURABLEOWNERSHIP}

The pre-flood consumer durables, ownership analysis revealed that majority (94.11\%) of the respondents owned TV, $92.15 \%$ of the respondents owned a refrigerator, $50.98 \%$ owned a washing machine out of which the consumer durables which was mostly $(76.92 \%)$ damaged/destroyed was washing machine followed by refrigerator $(70.21 \%)$, TV(66.66\%).

\section{BEHAVIORAL PATTERN SHOWN TOWARDS CONSUMER DURABLES LOST INFLOOD.}

- In the case of all the three consumer durables the decision taken for damaged durables was that of repair- T.V (65.62\%), refrigerator (84.84\%) and washing machine(55\%).

- But all those who had taken the decision to repurchase - TV (9.37\%), refrigerator (6.06\%) and washing machine $(10 \%)$ made the purchase of the consumer durables within a period of one month afterflood.

- The analysis on the category (based on price range) of consumer durables owned before flood reveals that, $100 \%$ of the respondents in all the three category of consumer durables, owned economy range. But the analysis on the category (based on price range) of consumer durables owned after flood reveals that, in case of television and washing machine $100 \%$ of the respondents have purchased premium range. But in case of refrigerator, $50 \%$ of the respondents have purchased standard range of refrigerator and rest $50 \%$ premium range ofrefrigerators.

- $100 \%$ of the respondents have received government's initial flood relief fund of Rs.10,000 which was utilised for primary necessities like cleaning of their houses, replacement of utensils, bed etc. But the analysis shows that majority of the prospective consumers( who repaired or were undecided with regard to lost consumer durables) are not going to replace their damaged durables even if they are to receive government's additional flood relieffund.

- In case they replace their damaged consumer durables the prime criteria behind their purchase decision would be features offered in the product (rank point -96), brand preference (86), product discounts and economy (74), and advertisements(73).

- With respect to financing of consumer durables majority of the consumers in the flood affected areas prefer ready cash payment in case of TV (33.33\%) and washing machine (16.66\%), whereas in case of refrigerator (25\%) they prefer installment scheme.

- $90.19 \%$ of the respondents are not aware about the fact that home insurance policy protects consumer durables against natural calamities. Even out of the $10 \%$ who are aware that home insurance policy protects the consumer durables against damages out of natural calamities $80 \%$ do not own a home insurance policy. Among the $90 \%$ who were unaware that home insurance policy protects the consumer durables against damages out of natural calamities majority $(56.52 \%)$ are averse to such a policy even after the severe flood situation faced bythem.

- On Service Provisions of Various Brands in TV, Refrigerator and Washing Machines and its Effectiveness. 
COMPARATIVE ANALYSIS OF OFFERS MADE BY VARIOUS BRANDS IN THEPOST FLOODSCENARIO

\begin{tabular}{|l|c|c|c|c|c|c|}
\hline \multicolumn{1}{|c|}{ Offers Made } & \multicolumn{6}{|c|}{ Brands in Consumer Durables } \\
\cline { 2 - 7 } & Panasonic & Godrej & IFB & Bosch & Samsung & LG \\
\hline $\begin{array}{l}\text { 1) Free Service } \\
\text { Camp }\end{array}$ & YES & YES & YES & YES & $\mathrm{X}$ & YES \\
\hline 2) Spare Part Charge & Nil & $\begin{array}{c}50 \% \\
\text { Discount }\end{array}$ & $\begin{array}{c}25 \% \\
\text { Discount }\end{array}$ & $\begin{array}{c}50 \% \\
\text { Discount }\end{array}$ & $\begin{array}{c}50 \% \\
\text { Discount }\end{array}$ & $\begin{array}{c}50 \% \\
\text { Discount }\end{array}$ \\
\hline 3) Labour Charge & $\mathrm{X}$ & Free & Free & $\mathrm{X}$ & Free & Free \\
\hline 4) Exchange Offers & $\mathrm{X}$ & YES & YES & $\mathrm{X}$ & $\mathrm{X}$ & $\mathrm{X}$ \\
\hline $\begin{array}{l}\text { 5) Customer Care } \\
\text { Nos. for booking visit }\end{array}$ & $\mathrm{X}$ & $\mathrm{X}$ & $\mathrm{X}$ & Yes & $\mathrm{X}$ & $\mathrm{X}$ \\
\hline $\begin{array}{l}\text { 6) Customer Service } \\
\text { Vans. }\end{array}$ & $\mathrm{X}$ & $\mathrm{X}$ & $\mathrm{X}$ & $\mathrm{X}$ & Yes & $\mathrm{X}$ \\
\hline $\begin{array}{l}\text { 7) Purchase at Rs.0 } \\
\text { Down Payment }\end{array}$ & $\mathrm{X}$ & $\mathrm{X}$ & $\mathrm{X}$ & $\mathrm{X}$ & $\mathrm{X}$ & Yes \\
\hline
\end{tabular}

These service provisions proved to be very effective for LG and Samsung because those who repurchased the consumer durables after flood preferred these brands which gave higher service provisions in all three classes of consumer durables considered for study.

\section{PRE FLOOD WHITE GOOD BRAND OWNED}

\begin{tabular}{|c|c|c|c|c|c|c|c|c|}
\hline \multirow{3}{*}{ White Goods } & \multicolumn{8}{|c|}{ BRAND } \\
\hline & \multicolumn{2}{|l|}{$\mathbf{L G}$} & \multicolumn{2}{|l|}{ Samsung } & \multicolumn{2}{|l|}{ Onida } & \multicolumn{2}{|l|}{ Whirlpool } \\
\hline & $\begin{array}{c}\text { No: Of Respon- } \\
\text { Dents }\end{array}$ & $\%$ & $\begin{array}{c}\text { No:Of Respon- } \\
\text { Dents }\end{array}$ & $\%$ & $\begin{array}{c}\text { No: Of Respon- } \\
\text { Dents }\end{array}$ & $\%$ & $\begin{array}{c}\text { No:Of Respon- } \\
\text { Dents }\end{array}$ & $\%$ \\
\hline TV & 0 & 0.00 & 2 & 66.66 & 1 & 33.33 & 0 & 0.00 \\
\hline Refrigerator & 2 & 100.00 & 0 & 0.00 & 0 & 0.00 & 0 & 0.00 \\
\hline $\begin{array}{l}\text { Washing } \\
\text { machine }\end{array}$ & 0 & 0.00 & 1 & 50.00 & 0 & 0.00 & 1 & 50.00 \\
\hline
\end{tabular}

Source: Primary Data

\section{POST FLOOD WHITE GOOD BRAND PURCHASED}

\begin{tabular}{|l|c|c|c|c|c|c|c|c|}
\hline \multirow{3}{*}{ White Goods } & \multicolumn{9}{|c|}{ Brand } \\
\cline { 2 - 10 } & \multicolumn{2}{|c|}{ LG } & \multicolumn{2}{c|}{ Samsung } & \multicolumn{2}{c|}{ Haier } & \multicolumn{2}{c|}{ Whirlpool } \\
\cline { 2 - 10 } & $\begin{array}{c}\text { No: Of } \\
\text { Respon-Dents }\end{array}$ & $\%$ & $\begin{array}{c}\text { No:Of Respon- } \\
\text { Dents }\end{array}$ & $\%$ & $\begin{array}{c}\text { No:Of } \\
\text { Respon-Dents }\end{array}$ & $\%$ & $\begin{array}{c}\text { No:Of Respon- } \\
\text { Dents }\end{array}$ & $\%$ \\
\hline TV & 2 & 66.66 & 1 & 33.33 & 0 & 0.00 & 0 & 0.00 \\
\hline Refrigerator & 1 & 50.00 & 1 & 50.00 & 0 & 0.00 & 0 & 0.00 \\
\hline $\begin{array}{l}\text { Washing } \\
\text { machine }\end{array}$ & 0 & 0.00 & 0 & 0.00 & 1 & 50.00 & 1 & 50.00 \\
\hline
\end{tabular}

Source: Primary Data

- $\quad 47.09 \%$ of the respondents were not aware of the free service camps, discount offers, instalment schemes etc provided by the various brands. For those became aware about it, the main source of information wasnewspapers.

- On Service Provisions of Various Dealers in TV, Refrigerator and Washing Machines and itsEffectiveness. 


\section{COMPARITIVE ANALYSIS OF OFFERS MADE BY VARIOUS DEALERS IN THE POST FLOODSCENARIO}

\begin{tabular}{|c|c|c|c|c|c|}
\hline \multirow[b]{2}{*}{ Offers Made } & \multicolumn{5}{|c|}{ Dealers } \\
\hline & Reliance Digital & $\begin{array}{c}\text { Nandilath } \\
\text { G-Mart }\end{array}$ & Bismi & QRS & White Mart \\
\hline $\begin{array}{l}\text { Free Service } \\
\text { Camps }\end{array}$ & Yes & $\mathrm{X}$ & Yes & $\mathrm{X}$ & Yes \\
\hline Labour Charge & Free & $X$ & Free & $\mathrm{X}$ & Yes \\
\hline $\begin{array}{l}\text { Discount on } \\
\text { Spare Parts }\end{array}$ & $5 \%$ & $\mathrm{X}$ & $\mathrm{X}$ & $\mathrm{X}$ & $\mathrm{X}$ \\
\hline $\begin{array}{l}\text { Bonus/Discount } \\
\text { Offers }\end{array}$ & $\begin{array}{c}\text { Additional } \\
\text { Rs. } 1,000 \text { bonus } \\
\text { exchange offer } \\
\text { for } 1,000 \mathrm{~T} . \mathrm{V} \text {, } \\
\text { Refrigerators and } \\
\text { Washing } \\
\text { Machines }\end{array}$ & $\mathrm{X}$ & $\begin{array}{c}50 \% \\
\text { Discount on } \\
\text { home } \\
\text { appliances }\end{array}$ & $\begin{array}{c}\text { Special } \\
\text { Discount offers }\end{array}$ & $\begin{array}{l}\text { Mega Discount } \\
\text { Sale. }\end{array}$ \\
\hline $\begin{array}{l}\text { Zero Down } \\
\text { Payment } \\
\text { Purchase Scheme }\end{array}$ & 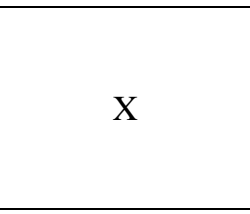 & $\begin{array}{l}\text { YES - only } \\
\text { for LG }\end{array}$ & $\begin{array}{l}\text { YES - for } \\
\text { LG, Sony, } \\
\text { Panasonic, } \\
\text { Samsung \& } \\
\text { Bosch. }\end{array}$ & $\mathrm{X}$ & $\mathrm{X}$ \\
\hline \begin{tabular}{|l|} 
Toll Free Number \\
Facility
\end{tabular} & $\mathrm{X}$ & $\mathrm{X}$ & YES & $\mathrm{X}$ & $\mathrm{X}$ \\
\hline Finance Schemes & $\mathrm{X}$ & $\begin{array}{c}\text { Interest Free } \\
\text { Instalment } \\
\text { Scheme. }\end{array}$ & $\mathrm{X}$ & $\begin{array}{l}\text { Purchase of } \\
\text { home } \\
\text { appliances at } \\
\text { Rs.1/- and } \\
\text { balance on } \\
\text { instalment } \\
\text { basis starting } \\
\text { from next } \\
\text { month. }\end{array}$ & $\begin{array}{l}\text { Purchase of home } \\
\text { appliances at Rs.1/- } \\
\text { and balance on } \\
\text { instalment basis } \\
\text { starting from next } \\
\text { month. }\end{array}$ \\
\hline \begin{tabular}{|l|} 
Free Gifts on \\
Every Purchase \\
\end{tabular} & $\mathrm{X}$ & $\mathrm{X}$ & $\mathrm{X}$ & $X$ & Yes \\
\hline $\begin{array}{l}\text { Family Pack } \\
\text { Offer }\end{array}$ & $\mathrm{X}$ & $\mathrm{X}$ & $\mathrm{X}$ & $\mathrm{X}$ & $\begin{array}{l}\text { Provision of entire } \\
\text { home appliances } \\
\text { required by family } \\
\text { for Rs. } 69,990 /-.\end{array}$ \\
\hline Exchange Offers & $\mathrm{X}$ & $\mathrm{X}$ & $\mathrm{X}$ & $\begin{array}{c}\text { On home } \\
\text { appliances of } \\
\text { any condition }\end{array}$ & \begin{tabular}{|c|} 
Onhome \\
appliances of any \\
condition
\end{tabular} \\
\hline Help Desk & $\mathrm{X}$ & $\mathrm{X}$ & $\mathrm{X}$ & $\mathrm{X}$ & $\begin{array}{c}\text { Special help desk } \\
\text { facility for servicing } \\
\text { of home appliances } \\
\text { which needs to be } \\
\text { repaired on account } \\
\text { of flood. Service } \\
\text { provision at home } \\
\text { through booking } \\
\text { personally or by } \\
\text { phone. }\end{array}$ \\
\hline
\end{tabular}

The above depicted comparative analysis on offers made by various dealers in the post flood scenario shows that maximum offers (5/11) was made by White Mart, followed by Bismi (5/11), Reliance Digital (4/11), QRS (3/11), and at last Nandilath G- Mart (2/11). Through maximum service provisions to the flood affected victims white mart was able to 
reduce its downfall of sales in the month of August and September as compared to the dealers Pittapallil and Oxygen who were considered in the study.(Depicted through sales trend of the 3 dealers below).

SALES TREND (TV + REFRIGERATOR + WASHING MACHINE) OF THE THREE DEALERS FOR THE FIRST \& SECOND QUARTER (2017-18)

Source: Primary Data (Sales Figures - in Lakhs)

\section{SALES IN LAKHS}

SALES TREND (TV + REFRIGERATOR + WASHING MACHINE) OF THE THREE DEALERS FOR THE FIRST \& SECOND QUARTER (2018-19)

Source: Primary Data

- Majority of the consumers who repaired their damaged consumer durables did not avail the free service camps offered by the dealers and instead resorted to local mechanics as the cost charged by dealers even after all offers was too high compared to localmechanics.

- The respondents who availed dealers free services took the services of Pitapallil, QRS and Bismi and they were satisfied with the services provided by the concerned dealer in all the three category of consumerdurables.

- In case of future purchase of consumer durables the most preferred dealer in case of TV is Pitapalli\&Bismi, for refrigerater it is QRS, Pitapallil and Bismi and for washing machine it is Nandilath andBismi.

- For those respondents who repurchased their damaged consumer durables $71.42 \%$ were highly satisfied with the dealer deliveryterms.

- $47.09 \%$ of the respondents were not aware of the free service camps, discount offers, instalment schemes etc provided by the various brands. For those became aware about it, the main source of information wasnewspapers.

\section{CONCLUSIONS}

Overall the study reveals that there is no much prospects for enhancement of sales either for brands or dealers in consumer durables in the post flood scenario, as the flood affected areas in and around Kottayam municipality happens to be areas occupied by low income group who cannot afford a quick replacement of damaged consumer durables. The various service provisions offered to flood affected victims proved to be effective as it helped in enhancing their brand loyalty. Dealer services offered as a relief to flood victims even though satisfactory was not much availed by consumers owing to higher service charges as compared to local mechanics.

\section{REFERENCES}

1. Narendra Nathan, ET Bureau Updated: Aug 27,2018.

2. Logan Tina, "Profiting from Market Trends" Wiley Publications, 1807. 
3. Na Wang, (May, 2009) "A Marketing Analysis of the Household Appliances Market in Finland,A Case for the HaierGroup".

4. S.SriRanjini and Sangeetha, “A Study on the Marketing Strategies for the Home Appliancesin Supermarket."

5. Trans Stellar consulting group (2015), “Consumer Buying Behaviour (with special reference tohome appliances).",

6. MalayalaManorama : Aug 24, 2018; Aug 29, 2018; Aug 30, 2018; Sept. 1,2018; Sept.4, 2018; Sept.5,

7. 2018; Sept. 9, 2018; Sept.28, 2018; Sept.29, 2018; Oct.1, 2018.

8. The Times of India : Aug 24,2018. 
